\title{
Mobile banking services quality and its impact on customer satisfaction of Indonesian Islamic banks
}

\author{
Bayu Arie Fianto, Charissa Kezia Rahmawati, Indri Supriani \\ Faculty of Economic and Business, Universitas Airlangga, Surabaya, Indonesia
}

\section{Article History \\ Received : 23 November 2020 \\ Revised : 12 December 2020 \\ Accepted : 23 December 2020 \\ Published: 11 January 2021 \\ Keywords: \\ Mobile banking, Service quality, Customer satisfaction, Islamic banking, SEM \\ DOI: \\ https://doi.org/10.20885/JEKI.vol7.is s1.art5}

\section{JEL Classification: G21, L86, M15, M31}

\section{Corresponding author:}

bayu.fianto@feb.unair.ac.id

\section{Author's email: \\ charissa.kezia.rahmawati- \\ 2014@feb.unair.ac.id \\ indri.supriani-2018@pasca.unair.ac.id}

\section{Paper type:}

Research paper

Cite this article:

Fianto, B.A., Rahmawati, C.K., \& Supriani, I. (2021). Mobile banking services quality and its impact on customer satisfaction of Indonesian Islamic banks. Jurnal Ekonomi dan Keuangan Islam, 7(1), 59-76.

https://doi.org/10.20885/JEKI.vol7.is s1.art5

\section{Introduction}

Financial technology (FinTech) in Indonesia is growing rapidly (Darmansyah et al., 2020). With the world's largest Muslim population, Indonesia is becoming the most attractive country to utilize the prospect of Islamic FinTech. Pollari and Ruddenklau (2018) reported that there are about 167 FinTech companies with an investment of US\$182.3m in Indonesia. Besides, Indonesia, the fourth-largest population globally dominated by generations $\mathrm{Y}$ and $\mathrm{Z}$, is a great potential market to use financial digitalization (Bank Indonesia, 2019). Aulia et al. (2020) stated that technology would help the financial services industry increase their performances by 
reaching a wider community. Among the developments in FinTech, the most rapid growth is in mobile banking (m-banking) (Siyal et al., 2019).

M-banking is a self-service facility-service which improves customers' efficiency, convenience, and mobility in accessing bank services from their mobile devices at any time so long as they are wisely connected to the internet, without the presence of bank employees or fixed machines (Asmy et al., 2018; Baabdullah et al., 2019; Shankar and Rishi, 2020). Customers may access banks' financial services through m-banking such as checking account balances, account transfers, and paying bills (Sahoo, 2017). This technological development enables banks to satisfy customers with secure solutions through m-banking (Tam and Oliveira, 2015).

Recently, both conventional and Islamic m-banking have been popular among the public because $m$-banking offers benefits for the customer and banks, including reduced operational costs and increased time effectiveness (Alkhowaiter, 2020). Further, smartphone penetration has prompted bank customers' behavior changes to intensively use m-banking for their transactions (Fall et al., 2020). Bank Indonesia (2019) reports that $133 \%$ and $56 \%$ of the Indonesian population use mobile phones and are connected to the internet, respectively. These data are slightly higher than the world mobile subscription. The report also reveals that $51 \%$ of the Indonesian population are unbanked, which has become an enormous market potential.

Consequently, the above phenomenon forms an intense competition among Islamic bank institutions (Suhartanto et al., 2019), and changes customers' points of view of service quality presented by banks (Son et al., 2019). Moreover, Saptasari \& Aji (2020) discovered that perceived quality play a prominent role in shaping customer satisfaction towards Islamic bank in Indonesia. Thus, a study of customers' satisfaction with m-banking is urgently needed. Numerous studies, such as Zameer et al. (2015) in Pakistan, Sampaio et al. (2015) in India, Brazil, and United States, Mohammadi (2015) and Hamidi and Safareeyeh (2019) in Iran, Ofori et al. (2017) and Asiamah et al. (2019) in Ghana; Mbama and Ezepue (2018) in the United Kingdom; Ramadan and Aita (2018) and Baabdullah et al. (2019) in Saudi Arabia, Foroughi et al. (2019) in Malaysia, Shankar and Rishi (2020) and Arora and Sandhu (2018) in India, Mostafa (2020) in Egypt and Fall et al. (2020) in sub-Saharan Africa have been done.

Existing studies have widely discussed customers' satisfaction with m-banking. These studies reveal that mobile banking service quality has a significant relationship with customer satisfaction. Baabdullah et al. (2019) explain that analyzing the factors determining mobile banking use or, specifically, the impact of mobile banking service quality on customer satisfaction is necessary both at the individual and society level because the results could reduce 'billions' in charges. It is essential to understand customers' needs and find customers' desires for a product or service that exceeds customer expectations (Hamidi and Safareeyeh, 2019). Customers will be satisfied with the services provided when they feel that the service is suitable for their needs and expectations.

A study conducted by Hellier et al. (2003) explained that six core concepts regarding the measurement of customer satisfaction includes overall customer satisfaction, dimensions of pleasure, confirmation of expectations, repurchase interest, willingness to recommend, and consumer dissatisfaction. Specifically, Islamic banking should provide these six core concepts and include Sharia compliance assurance. Thus, Islamic banking plays a vital role in providing financial access based on Islamic principles (Zarrouk et al., 2016) for individuals and industries who do not use conventional banks that do not meet their spiritual needs (Imam \& Kpodar, 2016).

This study differs from previous studies in focusing on Islamic mobile banking in Indonesia, specifically on the top five brand index in the banking and finance category, in particular for Islamic banking subcategory (Top Brand Award, 2020b). The Top Brand Award has three particular parameters: First, Top of Mind awareness (the first bank mentioned by respondents when a financial institution is specified); Second, the Last Usage is the last bank used by respondents in one re-use cycle; and Third, Future Intention is the bank which respondents intend to use in the future (Top Brand Award, 2020a). The three metrics are used to get the Top Brand Index (TBI) by calculating each parameter's weighted average. The three appropriate indices reflect customer behavior to their bank. From the TBI results, the Top 5 Brand is 
awarded to Bank Rakyat Indonesia (BRI) Syariah, Bank Syariah Mandiri (BSM), Bank Negara Indonesia (BNI) Syariah, Bank Central Asia (BCA) Syariah, and Bank Muamalat.

Based on previous data and descriptions, this study is conducted to investigate the influential factors of the multidimensional concept of mobile banking service quality (enjoyment, security, ease, design, and application system) on Islamic banks' customer satisfaction in Indonesia.

\section{Literature Review and Hypothesis Development}

\section{Convenience Dimension}

The study conducted by Pinho and Soares (2011) defined perceived convenience as the extent to which the use of a specific technology, in particular Islamic m-Banking, is considered enjoyable for daily economic activities. The study conducted by Akram et al. (2020) found that the determinant of customer loyalty when a customer enjoys using Islamic mobile banking is a reflection of the convenience dimension. It affects their life-cycle, such as buying goods, receiving money, and investments; thus, customers will be loyal to the product because they feel satisfied. The point of that relationship is an essential part of satisfying, and how to obtain that feeling is enjoyment. M-banking may trigger satisfaction through pleasurable and experiential value resulted from using a mobile device to access banking services (Mostafa, 2020). Shankar and Rishi (2020) showed that convenience is a factor that affects the Islamic bank customer's willingness to adopt online mobile banking. Convenience includes access to convenience and transaction convenience. Thus, increasing the adoption rate of $\mathrm{m}$-banking caused by access and transaction convenience reflects customer satisfaction. Based on the above theoretical framework, the following hypothesis is proposed:

H1: The convenience dimension significantly and positively influences customer satisfaction with Islamic banks in Indonesia.

\section{Security Dimension}

The study conducted by Esther et al. (2020) explains that the security aspect in a mobile banking service is a common problem for financial institutions because weak security can lead to high potential loss. The study demonstrates that 'security' in mobile banking services contains security tokens, anonymity, and authentication. Besides financial information, mobile banking includes customers' data, such as an address, phone number, family identity, and salary. To minimize data loss risk regarding personal information, most financial institutions use anonymity to keep customers' privacy (Esther et al., 2020). Privacy reflects the interaction between customer and mobile banking (Hong and Thong, 2013). Albashrawi and Motiwalla (2017) mentioned that customers' data security is the bank's primary concern when customers interact with mobile banking activities. Customers' primary objective is to keep secret their data, money, and bank transactions rather than riskier hold cash; thus, customers are satisfied when their privacy is secure. Banks must maintain electronic data exchanges; studies from Iran mentioned that information security is a necessary part of a mobile banking system for bank customers (Safarpour, 2016).

Privacy and security are associated with financial risk; both are primary concerns of customers' trust. Trust in the system reflects that they are satisfied with Islamic mobile banking (Lim et al., 2017). Evidence from Germany showed that data security in financial technology, including mobile banking, significantly affects customers' intentions and level of use of this technology; repeat usage implies customer satisfaction (Stewart and Jürjens, 2018b). Customers are more likely to trust a new service if adequate security is provided for their transaction data (Singh and Srivastava, 2020).

Bahl \& Wali (2014) explained that customer information security reflects the company service quality offered to customers. Logically, most customers prefer a high-quality product, such as the security dimension, which will increase their satisfaction in using that secure product. In the context of Islamic mobile banking, there are several differences from conventional banks, where, security should be embedded in the privacy data and following Sharia principles as well as 
several Islamic deeds such as avoiding gharar and riba. Thus, it will lead to a higher level of customer satisfaction. With an excellent system security quality, customers feel safe in banking transactions (Mazaheri Asad et al., 2016). Based on this theoretical framework, the following hypothesis is proposed:

H2: The security dimension significantly and positively influences customer satisfaction with Islamic banks in Indonesia.

\section{Ease-of-Use Dimension}

Foroughi et al. (2019) stated that mobile banking's continued use is affected by perceived ease of use; perceived use encourages customer self-efficacy. Self-efficacy refers to clients' abilities and skills that they are cognizant of after first-time use but before making a sensible decision about continuation. Vanessa (2015) defined perceived ease as the customer feels free of problems and worries when using technology. An ease of use of technology means that its operation and techniques are not complicated and they require minimum effort mentally and physically (Suhartanto et al., 2019). Based on the study conducted by Alkhowaiter (2020), the ease dimension is one-factor affecting customer satisfaction. Ease of use includes digital payment and banking methods, which most people use every day. Customer needs mobile banking to simplify their activities; if mobile banking can provide that easiness, it will increase customer satisfaction.

Evidence from the Iran Islamic Bank showed that perceived ease of use is a significant factor for the bank to adopt mobile banking to improve customer satisfaction (Hanafizadeh et al., 2014). In the context of Islamic bank in Indonesia, Kholid (2019) revealed that effort expectancy, which consists of four indicators including fair, easy to learn, understandable and easy to master, has significant and positive effect on the customer intention to use Islamic mobile banking. Additionally, in the context of Islamic bank, for customers it is made easy by features of Islamic mobile banking, namely, zakah, infaq, shadaqah, qurban, umrah, and hajj features that differentiate the Islamic product from conventional banks. As mentioned above, Indonesia's Muslim population is high enough to accommodate religiosity in Islamic mobile banking, thus leading to Muslim customers' satisfaction. From the theoretical framework above, the hypothesis is proposed as follows:

H3: The ease-of-use dimension significantly and positively influences customer satisfaction with Islamic banks in Indonesia.

\section{Design Dimension}

Nowadays, m-banking for Islamic banks affects customers' habits, based on the study conducted by Mohd Thas Thaker et al. (2019). They show that customers intend to continuously use mobile banking because of its convenience and customer service quality. One customer service quality is the design of the mobile banking application. Most mobile banking design is Augmented Reality (A.R.). Ginting et al. (2020) mention that A.R. integrates the tools of banking activities such as scanning for the nearest ATM and bank, automatic information of debit, and that customer services can improve customer satisfaction. Al-Otaibi et al. (2018), in their study, stated that information quality and interface design are two main factors affecting customer satisfaction with Islamic banks in the UK and Saudi Arabia. The interface design is how mobile banking provides useful information in an understandable design.

Evidence from Germany is that interface design is one of three major factors that encourage banks and customers to adopt financial technology, including mobile banking (Stewart and Jürjens, 2018a). A friendly interface design may prompt users to use Islamic mobile banking. The design can escalate customers' satisfaction because they feel entertained with an attractive design (e.g., colorful) and increase the level of continued use. The aesthetic design of mobile platforms, including mobile banking, can attract consumers to the technology, thus increasing interaction between the user and the technology (Arcand et al., 2017a). The feeling of happiness, continued use, and a sense of interest will lead to a higher customer satisfaction. Based on the literature framework above, the hypothesis is proposed as follows: 
H4: The design dimension significantly and positively influences customer satisfaction with Islamic banks in Indonesia.

\section{Application System Dimension}

Based on prior studies, a mobile banking system consists of three coherent technologies namely network technology, website technology, and mobile phone technology (Masrek et al., 2014). Optimization of those three aspects can increase customer trust in using Islamic mobile banking and increase customer satisfaction. Koo and Wati (2010) stated that a variable quality system influences trust and trust influences customer satisfaction. A better application system provides reliable information to customers, such as cash outflow, historical transactions, and the current balance. Reliable information derived by customers will improve their satisfaction. The study conducted by Asad et al. (2016) defined that the application system dimension, particularly system navigability, be characterized by ease and speed of navigation, which means the system allows users to go where they want to go, e.g., the nearest bank branch. The second feature is an efficient search engine, which means customers can easily find what they search for in simple words. The third feature is a sufficient number of working links. One of the most used systems in mobile banking is a dynamic system. Octabriyantiningtyas et al. (2019) defined a dynamic system as one with fields to understand how things change all the time. Particularly in an Islamic mobile banking system, the system can provide time, prayer, budget information, current gold value, and other things that are updatable all the time.

The m-banking system implies that it provides net benefits and data integrity for customers, which may significantly affect customer satisfaction (Motiwalla et al., 2019). A better application system will increase usage by customers because they receive benefits, excellent service quality, and data security in banking activities; customer satisfaction is thus higher (Sharma and Sharma, 2019). Because of that impact, Hamidi and Safareeyeh (2019) analyzed the management's response. Management usually uses Customer Relationship Management (CRM) to investigate customer satisfaction regarding the m-banking application system by knowing the actual use, transaction activities, the total time spent on m-banking system, and other aspects. According to that study of e-bank in Iran, the usefulness of banking application system is one factor that can increase customer satisfaction. Based on the theoretical framework above, the hypothesis is:

H5: The application system dimension significantly and positively influences customer satisfaction with Islamic Bank in Indonesia.

\section{Research Methods}

A standardized self-administered questionnaire was developed, based on an extensive previous literature review of prior studies, and all the variables were adopted from existing research. This study conducted pilot testing to re-assure the validity of the measurement variable which used in this research. Moreover, this study uses convenience sampling, which led based on the respondents' easiness and accessibility (Raza et al., 2020). The investigation has resulted in 119 respondents. This study's sample consists of 100 respondents who at least had ever made one financial transaction using selected Islamic mobile banking. All respondents had used Islamic mobile banking with one of the Top 5 Brand Award (BNI Syariah, BRI Syariah, BCA Syariah, BSM, Bank Muamalat). Moreover, 19 respondents were excluded because they did not meet the study criteria.

The respondent of this study has met the minimum sample size estimation based on Hair et al. (2011) method which well-known as "10 times-rule". This method requires the sample should be 10 times the greatest number of formative indicators used to measure a construct (Hair et al., 2011) or greater than the maximum number of inner or outer model links at any latent variable in the model multiplied by 10 (Goodhue et al., 2018). This study consists of five inner model links and each of them measured by three reflective indicators (outer model), thus the sample size of this study should be more than 50. Therefore, in this study, we used 100 respondents which fulfilled the sample criteria. 
The online survey was carried out in December 2019 and distributed online via social media, which can reach shariah banks' customers all over Indonesia. The research tool was constructed on a five-point Likert scale varying between strongly disagree (1) and strongly agree (5). The questionnaire has two components: the respondent's demographics and the respondent's assessment of the Islamic mobile banking variable indicators. The second component comprised of five independent variables and one dependent variable is presented in Table 1.

Table 1. Variable Measurements

\begin{tabular}{|c|c|c|}
\hline Variable & Indicator & Source \\
\hline X1: & X1.1: Islamic m-banking application is entertaining to use. & \multirow{3}{*}{$\begin{array}{l}\text { Shankar and Rishi } \\
(2020)\end{array}$} \\
\hline Convenience & $\mathrm{X} 1.2$ : Islamic $\mathrm{m}$-banking application is very convenient to use. & \\
\hline Dimension & $\mathrm{X} 1.3$ : Islamic $\mathrm{m}$-banking application is very entertaining to use. & \\
\hline X2: Security & X2.1: My personal information is protected. & \multirow{3}{*}{$\begin{array}{l}\text { Arcand et al. } \\
\text { (2017) and Raza et } \\
\text { al. (2020) }\end{array}$} \\
\hline Dimension & $\begin{array}{l}\text { X2.2: Islamic m-banking application provides security when } \\
\text { making transaction. }\end{array}$ & \\
\hline & $\begin{array}{l}\text { X2.3: Confidentiality is guaranteed when using Islamic m-banking } \\
\text { application. }\end{array}$ & \\
\hline \multirow[t]{3}{*}{$\begin{array}{l}\text { X3: Ease } \\
\text { Dimension }\end{array}$} & $\begin{array}{l}\text { X3.1: Islamic m-banking application can be accessed everywhere } \\
\text { and anytime. }\end{array}$ & \multirow[t]{3}{*}{$\begin{array}{l}\text { Zhou, Lu and } \\
\text { Wang (2010) }\end{array}$} \\
\hline & $\begin{array}{l}\text { X3.2: Islamic m-banking application makes my banking activities } \\
\text { easier. }\end{array}$ & \\
\hline & $\begin{array}{l}\text { X3.3: Transactions using Islamic m-banking application are on } \\
\text { time. }\end{array}$ & \\
\hline \multirow[t]{2}{*}{ X4: Design } & $\begin{array}{l}\text { X4.1: The design of Islamic m-banking application is exciting. } \\
\text { X4.2: The design of Islamic m-banking application design is very } \\
\text { creative. }\end{array}$ & \multirow[t]{2}{*}{$\begin{array}{l}\text { Arcand et al. } \\
(2017)\end{array}$} \\
\hline & $\begin{array}{l}\text { Display of banking services in Islamic m-banking } \\
\text { application is attractive. }\end{array}$ & \\
\hline \multirow{3}{*}{$\begin{array}{l}\text { X5: } \\
\text { Application } \\
\text { System }\end{array}$} & Islamic m-banking application can be accessed quickly. & \multirow[t]{3}{*}{ Raza et al. (2020) } \\
\hline & $\begin{array}{l}\text { Transfer of accounts can be done quickly on Islamic m- } \\
\text { banking application. }\end{array}$ & \\
\hline & $\mathrm{X} 5.3$ : Islamic m-banking is user-friendly. & \\
\hline \multirow{3}{*}{$\begin{array}{l}\text { Y: Customer } \\
\text { Satisfaction }\end{array}$} & I feel satisfied when using Islamic m-banking application. & \multirow{3}{*}{$\begin{array}{l}\text { Baabdullah et al. } \\
\text { (2019) }\end{array}$} \\
\hline & $\begin{array}{l}\text { I am satisfied with all the services available in the Islamic } \\
\text { m-banking application. }\end{array}$ & \\
\hline & $\begin{array}{l}\text { Islamic m-banking application is in accordance with my } \\
\text { expectations. }\end{array}$ & \\
\hline
\end{tabular}

This study uses Partial Least Squares (PLS) for structural question modeling. PLS can assist researchers in investigating relationships among the variables they observe (Rigdon et al., 2010). As PLS analysis can process the data from any scale, it is suitable for weak theoretical foundation models and does not require an assumption of normality in the data. Structural Equation Modeling (SEM) is the analytical method used to test the hypotheses. PLS-SEM is the most common method for analyzing social science issues. PLS-SEM experienced an increasing dissemination in a vast field. Recent method analysis has extended PLS-SEM methodological approach to accommodate additional complicated models and handle knowledge inadequacies like heterogeneity (Joe et al., 2014). PLS examines two models, the outer and inner models, to determine the result of this study.

\section{Results and Discussion}

\section{Respondents' Demographic}

The demographic characteristics of the respondents are given in Table 2. The samples are 100 respondents, the majority (65\%) is female, and the rest 35\% is male. In terms of age distribution, 
the dominant group was under 24 years old $(66 \%)$, this indicates that the result represents the perception of younger people (Sen et al., 2020). Additionally, the rest were either between $25-29$ years old $(25 \%)$ or $40-58$ years old $(8 \%)$.

Table 2. Demographic Characteristics of the Respondents

\begin{tabular}{|c|c|c|c|}
\hline Characteristics & Category & Frequency & Percentage \\
\hline Gender & $\begin{array}{l}\text { Male } \\
\text { Female }\end{array}$ & $\begin{array}{l}35 \\
65\end{array}$ & $\begin{array}{l}35 \% \\
65 \%\end{array}$ \\
\hline Age & $\begin{array}{l}\text { Under } 24 \text { years old } \\
25-39 \text { years old } \\
40 \text { - } 58 \text { years old } \\
\text { Over } 59 \text { years old }\end{array}$ & $\begin{array}{c}66 \\
25 \\
8 \\
1\end{array}$ & $\begin{array}{l}66 \% \\
25 \% \\
8 \% \\
1 \%\end{array}$ \\
\hline Occupation & $\begin{array}{l}\text { Government Employees } \\
\text { Small Business } \\
\text { Research Assistant } \\
\text { Private Employees } \\
\text { Honorary staff } \\
\text { Student } \\
\text { Employees of State-Owned Enterprises } \\
\text { Security }\end{array}$ & $\begin{array}{c}19 \\
6 \\
2 \\
35 \\
2 \\
30 \\
1 \\
1\end{array}$ & $\begin{array}{c}19 \% \\
6 \% \\
2 \% \\
35 \% \\
2 \% \\
30 \% \\
1 \% \\
1 \%\end{array}$ \\
\hline Income & $\begin{array}{l}\text { Less than Rp. } 2.500 .000 \\
\text { Rp. } 2.500 .001-\text { Rp. } 5.000 .000 \\
\text { Rp. 5.000.001 - Rp. } 10.000 .000 \\
\text { More than Rp. } 10.000 .001\end{array}$ & $\begin{array}{c}42 \\
27 \\
22 \\
9\end{array}$ & $\begin{array}{c}42 \% \\
27 \% \\
22 \% \\
9 \%\end{array}$ \\
\hline $\begin{array}{l}\text { What Mobile Banking You } \\
\text { Have Used? }\end{array}$ & $\begin{array}{l}\text { BNI Syariah } \\
\text { BRI Syariah } \\
\text { BCA Syariah } \\
\text { BSM } \\
\text { Bank Muamalat }\end{array}$ & $\begin{array}{c}45 \\
7 \\
2 \\
38 \\
8\end{array}$ & $\begin{array}{c}45 \% \\
7 \% \\
3 \% \\
38 \% \\
8 \%\end{array}$ \\
\hline $\begin{array}{l}\text { Experience of Using Mobile } \\
\text { Banking }\end{array}$ & $\begin{array}{l}\text { Less than } 1 \text { year } \\
1-2 \text { years } \\
3-4 \text { years } \\
\text { More than } 4 \text { Years }\end{array}$ & $\begin{array}{l}20 \\
31 \\
24 \\
25\end{array}$ & $\begin{array}{l}20 \% \\
31 \% \\
24 \% \\
25 \%\end{array}$ \\
\hline $\begin{array}{l}\text { How Many Times You } \\
\text { Access Your Mobile } \\
\text { Banking? }\end{array}$ & $\begin{array}{l}\text { Not Everyday } \\
1-3 \text { Times/Day } \\
4-6 \text { Times/Day } \\
\text { More than } 6 \text { Times/Day }\end{array}$ & $\begin{array}{c}79 \\
15 \\
4 \\
2\end{array}$ & $\begin{array}{l}79 \% \\
15 \% \\
4 \% \\
2 \%\end{array}$ \\
\hline $\begin{array}{l}\text { What Kind of the } \\
\text { Transaction that You Use } \\
\text { Intensively? }\end{array}$ & $\begin{array}{l}\text { Transfer } \\
\text { Payment } \\
\text { Purchase } \\
\text { Balance Check }\end{array}$ & $\begin{array}{l}58 \\
17 \\
14 \\
11\end{array}$ & $\begin{array}{l}58 \% \\
17 \% \\
14 \% \\
11 \%\end{array}$ \\
\hline $\begin{array}{l}\text { The Reason Why You Use } \\
\text { Mobile Banking? }\end{array}$ & $\begin{array}{l}\text { Accessible Anytime - Anywhere } \\
\text { More Secure (Safety) } \\
=\text { Faster - Convenience } \\
\text { Advanced Technology }\end{array}$ & $\begin{array}{l}72 / 100 \\
31 / 100 \\
73 / 100 \\
28 / 100\end{array}$ & $\begin{array}{l}72 / 100 \% \\
31 / 100 \% \\
73 / 100 \% \\
28 / 100 \%\end{array}$ \\
\hline
\end{tabular}

Source: (Data Processing)

Moreover, Table 1 reported that there is one respondent who is more than 59 years old. This result is in line with a previous study conducted by Mohd Thas Thaker et al. (2020), which stated that youngsters become potential customers in using Islamic bank's products because they actively engage in social media.

In the context of occupation, we can confirm that the respondents come from a varied profession, which indicates that all society levels are using Islamic mobile banking. The table demonstrated that private employee is the most common occupation accounted for $35 \%$, 
followed by student (30\%) and government employees (19\%). The rest of the respondents were the owner of small business $(6 \%)$, research assistant $(2 \%)$, honorary staff $(2 \%)$, housewives $(4 \%)$, employee of State-Owned Enterprises (1\%), and security (1\%).

Moreover, respondents' monthly income is categorized into four levels. Table 2 shows that the great majority of the respondents earn under Rp. $2.500 .000(66 \%), 27 \%$ respondent monthly income was Rp. 2.500.001 - 5.000.000, 22\% respondent earn Rp. 5.000.001 - Rp. 10.000.000, and $9 \%$ of respondents earn more than Rp. 10.000.000. As seen from the demographic point, the respondent used in this research was dominated by BNI Shariah's customers, which is almost a half of the respondents (45\%), followed by BSM's customers (38\%). In comparison, the rest of the respondents are the customers of Bank Muamalat (8\%), BRI Syariah (7\%), and BCA Syariah (2\%).

In terms of how long they used mobile banking, 31\% used mobile banking between $1-2$ years, $25 \%$ of the respondent experience of using mobile banking for more than four years, $24 \%$ of the respondent has experienced mobile banking between $3-4$ years, and 20\% respondent used less than 1-year mobile banking. Moreover, $79 \%$ of the respondents declared that mobile banking does not become their daily routine as can be seen from table 1 where they do not access their mobile banking every day. $15 \%, 4 \%$, and $2 \%$ of respondents accessed mobile banking 1-3 times, 4- 6 times, and more than 6 days in a day, respectively.

Referring to table 2, more than half of the respondents (58\%) answered they intensively utilize their mobile banking for transfer transactions purposes. While payment transaction is intensively used by $17 \%$ of respondents, $14 \%$ stated that they usually used mobile banking for purchase, and 11\% were usually used for balance check transactions. The most prominent reason that triggered the respondent to use mobile banking is due toa better service in terms of time, convenience and accessibility. This result indicates that respondents selected those reasons about $73 / 100$ and $72 / 100$, respectively. At the same time, safety and advanced technology become the third $(31 / 100)$ and fourth $(28 / 100)$ reason why the respondents use Islamic mobile banking.

\section{Measurement Model}

Goodness-of-fit is a method to test whether the aggregate data are close to the mean. The goodness-of-fit result is presented in Table 3.

Table 3. Goodness-of-Fit of the Factors

\begin{tabular}{lrrr}
\hline Measurement & Result & Model Requirement & Test Decision \\
\hline CMIN/DF & 2.883 & CMIN/DF $<2.00$ is a good fit & not a good fit \\
PGFI & 0.526 & $0 \leq \mathrm{PGFI} \leq 1$ PGFI bigher, the better. \\
GFI & 0.692 & $0.80 \leq \mathrm{GFI} \leq 0.90$ is marginal fit & not a good fit \\
& RMSEA $<0.08$ is good fit & not a good fit \\
RMSEA & 0.138 & $\mathrm{RMSEA}<0.05$ is close fit & NFI $>0.90$ is good fit \\
NFI & 0.707 & $0.80 \leq \mathrm{NFI} \leq 0.90$ is marginal fit & not a good fit \\
CFI & 0.783 & $0.80 \leq \mathrm{CFI} \leq 0.90$ is marginal fit & not a good fit \\
& &
\end{tabular}

Source: (Data processing)

The first measurement uses degrees of freedom (DF). Data have a good fit if DF less than 2 (Foroughi et al., 2019). Table 3 shows that the result is 2,883 , which is not a good fit. The second indicator is the Parsimony Goodness of Fit Index (PGFI). Parsimony conformity is measured as a correction from GFI (Schermelleh-Engel et al., 2003). Its expected value is greater than 0.90 (Chauhan et al., 2019). The GFI indicates the representation level between the sample covariance matrix and the estimated population covariance matrix (Moliner et al., 2018). In 
general, the diversity in the sample is appropriate to or repressive with differences in the population.

Based on table 3, GFI's boundary is 0.8 to 0.9 to be considered a marginal fit, but the result is 0.692 . Therefore, there is not a good fit for the research model to the observed data. Root Mean Square Error of Approximation (RMSEA) is the mean root square approximation of the error. It is expected that a low value is approximately equal to 0.08 (Zhou, 2011). The result here is 0.138 , which is more than 0.08; thus, it is not a good fit. The Normed Fit Index (NFI) is a measure of a model suitability on a comparative basis with a baseline or null model (Shankar and Rishi, 2020). The null model is generally a model stated that the estimated model variables are not interconnected. Its expected high value is greater than 0.90 . The result is 0.707 , which is not a good fit for the population. The Comparative Fit Index (CFI) measures a comparative-based model's compatibility with a null model (Mbama and Ezepue, 2018). Its expected high value is more significant than 0.90 . The result of CFI is 0.783 , which is less than 0.90 . Therefore, the model is not a good fit. Thus, it requires a modification model as portrayed in Table 4.

Table 4. The Goodness-of-fit Results of the Modified Model

\begin{tabular}{|c|c|c|c|}
\hline Fit-Measurement & Result & Model Requirement & Test Decision \\
\hline CMIN/DF & 1.600 & CMIN/DF $<2.00$ is good fit & good fit \\
\hline PGFI & 0.562 & $\begin{array}{r}0 \leq \text { PGFI } \leq 1 \\
\text { PGFI higher, better. }\end{array}$ & marginal fit \\
\hline GFI & 0.835 & $\begin{array}{r}\text { GFI } \geq 0.90 \text { is good fit } \\
0,80 \leq \mathrm{GFI} \leq 0.90 \text { is marginal fit }\end{array}$ & marginal fit \\
\hline RMSEA & 0.078 & $\begin{array}{l}\text { RMSEA }<0.08 \text { is good fit } \\
\text { RMSEA }<0.05 \text { is close fit }\end{array}$ & good fit \\
\hline NFI & 0.856 & $\begin{aligned} \text { NFI }>0.90 \text { is good fit } \\
0.80 \leq \mathrm{NFI} \leq 0.90 \text { is marginal fit }\end{aligned}$ & marginal fit \\
\hline CFI & 0.939 & $\begin{array}{l}\text { CFI }>0.90 \text { is good fit } \\
0.80 \leq \mathrm{CFI} \leq 0.90 \text { is marginal fit }\end{array}$ & good fit \\
\hline
\end{tabular}

Source: (Data processing)

From Table 4, we confirm that the DF values are lower than the maximum value $(1.6<$ 2). The PGFI value is 0.562 , which is no improvement on the first model. However, as mentioned by Schermelleh-Engel et al. (2003), the range of values for PGFI is from zero (no fit) to one (perfect fit); thus, we may conclude that this model is marginally good. The value of GFI is 0.835 , which is between the suggested boundary values. The RMSEA value of 0.078 is less than 0.08 , which indicates a good fit. The NFI value is 0.856 , which indicates that the variables in the estimated model are not interconnected. Finally, the CFI value is 0.939 , which higher than the expected value. As a result, the revised model has a good level of fit.

\section{Tests of Validity and Reliability}

Hair et al. (2011) states that the recommended composite reliability values is between 0.60 to 0.70 in exploratory research. Additionally, Hair et al. (2010) declared that factor loading should be more than 0.6 and average variance extracted (AVE) is higher than 0.5. In details, Chin (1998) in Abd-El-Fattah \& Fakhroo (2012) explained that the loadings factor minimum value depends on the research subject, and 0.5 can be accepted. Table 5 described that two loading factors are above the cut-off value (0.50) based on Chin (1998) recommendation and 16 loading factors are between $0.6-0.7$ which met the minimum value suggested by Hair et al. (2011) and Hair et al. (2010).

The result in Table 5 also showed that validity test is met as AVE is higher than 0.5. Moreover, the recommended CR and Cronbach's alpha values to support convergent validity are 
higher than 0.7 (Tenenhaus et al., 2005). The reliability and construct reliability (CR) also show good results because all Cronbach's alpha values are above 0.60, and the CRs are above 0.70 (cutoff value). Thus, this result indicates all the discriminant validity requirements have been satisfied.

Table 5. The Validity and Reliability Measurements for All Constructs

\begin{tabular}{lrllr}
\hline Item & Factor Loading & CR & AVE & Cronbach's Alpha \\
\hline X1.1 & 0.818 & 0.755 & 0.513 & 0.699 \\
X1.2 & 0.753 & & & \\
X1.3 & 0.551 & & & 0.909 \\
X2.1 & 0.853 & 0.903 & 0.755 & \\
X2.2 & 0.869 & & & \\
X2.3 & 0.885 & & & 0.787 \\
X3.1 & 0.745 & 0.797 & 0.577 & \\
X3.2 & 0.932 & & & 0.913 \\
X3.3 & 0.555 & & & \\
X4.1 & 0.795 & 0.908 & 0.769 & \\
X4.2 & 0.837 & & & \\
X4.3 & 0.987 & & & \\
X5.1 & 0.646 & 0.747 & 0.501 & \\
X5.2 & 0.839 & & & \\
X5.3 & 0.619 & & & \\
Y1 & 0.752 & 0.826 & 0.614 & \\
Y2 & 0.799 & & & \\
Y3 & 0.798 & & & \\
\hline Source: (Data processing) & & &
\end{tabular}

\section{Hypothesis Testing}

From the hypotheses presented in Table 6, the study finds that the convenience (X1), security (X2), design dimensions (X4), and the application system (X5) have a significant influence on customer satisfaction in using Islamic mobile banking. However, the ease-of-use dimension (X3) has no significant impact on customer satisfaction.

Table 6. The Relationship Paths among the Constructs

\begin{tabular}{lrrrl}
\hline Hypothesized Path & Estimate & \multicolumn{1}{c}{ C.R. } & \multicolumn{1}{c}{ P } & \multicolumn{1}{c}{ Result } \\
\hline H1: Convenience Dimension $\rightarrow$ Customer Satisfaction & 0.290 & 2.658 & $0.008^{* * *}$ & Supported \\
H2: Security Dimension $\rightarrow$ Customer Satisfaction & 0.123 & 1.874 & $0.061^{*}$ & Supported \\
H3: Ease of Use Dimension $\rightarrow$ Customer Satisfaction & -0.148 & -0.977 & 0.329 & Not Supported \\
H4: Design Dimension $\rightarrow$ Customer Satisfaction & 0.165 & 2.333 & $0.020^{* *}$ & Supported \\
H5: Application System Dimension $\rightarrow$ Customer & 0.534 & 3.405 & $0.001^{* * *}$ & Supported \\
Satisfaction & & & & \\
\hline
\end{tabular}

Note: $* *, * *$, and $*$ denote two-tail statistical significance at $1 \%, 5 \%$, and $10 \%$, respectively.

Source: (Data processing)

First, this study examines the relationship between convenience and customer satisfaction (H1). Table 6 shows that the convenience dimension becomes a significant key factor influencing customer satisfaction in using Islamic mobile banking. This result proved by the probability value of convenience dimension is lower than $\alpha 1 \%(0.008<0.01)$. This result indicates that improvement in the m-banking convenience dimension will increase customer satisfaction significantly. This result agrees with Akram et al. (2020) which revealed that if the customers enjoy using mobile banking, it improves their satisfaction. Similarly, Kaura (2013) claimed that service convenience plays a vital role in boosting customer satisfaction with banking..

Shankar and Rishi (2020) explained that convenience, which includes access, transaction, and possession, has a significant impact on the intention to adopt mobile banking. The study shows that an intention to adopt mobile banking indicates that customers are satisfied with 
banks' service convenience. Furthermore, Alalwan et al. (2017) stated that when a bank offers a convenient, easy, and effortless service in m-banking, it is effectively increasing the satisfaction level. Additionally, Fianto et al. (2020) explained that Islamic banking should provide not only competitive returns but also have to assure that their products and services fulfilled the Shariah compliance in order to increase their customer satisfaction. The result of this study indicates that $\mathrm{m}$-banking provided by the top five Islamic banks in Indonesia has met customers' expectations of convenience, both financially and spiritually.

Second, $\mathrm{H} 2$ test the impact of the security dimension on customer satisfaction. This study reveals that the security dimension is supported as a determining factor in customer satisfaction. Table 6 shows that the estimate value is 0.123 and the probability is lower than $\alpha 10 \%(0.061<$ 0.1). Consequently, this study indicates that the security dimension is significant and positively affects customer satisfaction. This result inline with several prior studies, including Lim et al. (2017) and Ofori et al. (2017) which explained that banks should protect the customer's transaction information, money, and personal information to promote customer satisfaction. Moreover, Haider et al. (2018) confirmed that security is a crucial factor impacting the adoption of Islamic m-banking across genders. Additionally, Giovanis et al. (2019) and Shareef et al. (2018) portrayed that mobile banking security is the most significant factor influencing customer trust, reflecting the level of customer satisfaction. They explained that security is positively related to technological issues while transferring money and paying bills via mobile banking. The most recent study conducted by Alkhowaiter (2020) discovered that security was the best predictor affecting digital payment and banking adoption in GCC countries. Customers' adoption of mbanking suggests they are satisfied with the bank's security service quality.

Asmy et al. (2019) argued that Islamic bank security had become the most notable factor. Islamic m-banking users' security expectations have transformed to become the primary need in a financial services platform. In Islamic banking, it is similar to conventional banking for the security dimension with privacy and transaction maintenance. Still, there is also security in the Islamic scheme, Islamic financial transactions, and profit-sharing. If Islamic mobile banking provides a secure service, customers will not worry about their financial transactions and data privacy. Finally, it will lead to increased satisfaction. From the results, respondents were more satisfied if Islamic mobile banking provides a high level of security.

This study tests the correlation between the design dimension and customer satisfaction (H4). The design dimension has a significant impact on affecting customers' attention through a friendly, catchy interface. The factor's estimated value is 0.165 with a probability value lower than $\alpha 5 \%(0.02<0.005)$. From this data, we can confirm that an attractive design has a positive and significant impact on customer satisfaction. Previous studies such as Al-Otaibi et al. (2018) and Raza et al. (2020) explained that when the design of m-banking is highly aesthetic and wellorganized, it enhances customer satisfaction. Furthermore, Mbama and Ezepue (2018) suggested that bank managers should pay more attention to a service quality that creates convenience for their customers because it plays an essential role in affecting customer satisfaction. In a broader context, Sampaio et al. (2015) found that, in Brazil, India, and the USA, the convenience of using mobile banking has directly affected customer satisfaction.

In the Islamic bank context, the interface design of Islamic m-banking can provide an interface with Islamic nuances which can attract Muslim customers. The first impression of a customer regarding Islamic mobile banking occurs when they first open the application. If the Islamic bank can provide a better interface design, customers will be more satisfied. Nowadays, the younger generation uses mobile banking; those customers prefer mobile banking with a friendly design. Thus, interface design has a significant positive effect on customer satisfaction.

This study tests the application system's influence on customer satisfaction for the top five Indonesian Islamic banks (H5). This study finds that the application system is the most significant factor in influencing customer satisfaction. The factor has an estimated value of 0.534 and a probability of less than $\alpha 1 \%(0.001<0.01)$. This result is supported by Motiwalla et al. (2019) who revealed that, in Islamic banking, an excellent application system provides reliable information, and data integrity will improve the customer's satisfaction. The reason is the better, 
more effective the application system leads to the perceived usefulness. Mostafa (2020) shows that when a bank develops a quality application system, avoids system crashes, and offers technical support, customers are more satisfied. The application system is at the core of Islamic mobile banking. This aspect contains system navigability, network technology, and more features that can increase the application's use. A useful feature for Islamic banks is to assist Muslim customers in rakat calculation, scheduled infaq and prayers. Such functional technology can quickly assist customers in their financial activities. These features will lead to higher satisfaction in an Islamic bank's customers.

Table 6 confirms that the ease-of-use variable does not significantly affect satisfaction in using Islamic mobile banking (H3). This result reflected by the probability value is higher than alpha. In contrast, Albashrawi and Motiwalla (2019) and Alkhowaiter (2020) discovered that ease of use improves customer satisfaction. In those studies, ease of use is relevant to traditional customers who know the technology, so they prefer to use mobile banking as their financial assistant. Conversely, table 6 agrees with Shan-Chun et al. (2003) which stated that modern customers have high technology useability. They need a more useful and faster facility, not only easy-to-use facility because modern customers are already smart with gadgets. Evidence from Indonesia, Suhartanto et al. (2019) proved that perceived ease-of-use, perceived usefulness, and religiosity explain $27.4 \%$ of user satisfaction variance, which implies that perceived ease-of-use is not crucial in customer satisfaction. Similarly, Riyanto (2020) examines the impact of ease of use of Islamic mobile banking, which includes time, place, and transaction towards customer's need. This study discovered that Islamic m-banking in Indonesia still does not accommodate several transactions, such as did not support electronic bills. Therefore, the ease of use does not accommodate the customer's needs, which affects the customer's satisfaction.

\section{Conclusion}

This study assessed the relationship of Islamic mobile banking service quality, represented by five dimensions: convenience, security, ease of use, application design, and application system, towards customer satisfaction in Indonesia. By applying the PLS-SEM approach and involving 100 respondents who are users from Top 5 Brand Award of Islamic mobile banking, this study reported that convenience, security, interface design, and application system of Islamic mobile banking play a significant role in shaping customer satisfaction. In contrast, the ease of use is found to have an insignificant impact on affecting customer satisfaction.

Based on the results, this study shows that the application system dimension is the most significant factor affecting customer satisfaction in the Islamic banking awarded Top 5 Brand. Thus, this study suggests that Indonesian Islamic banks should offer better mobile banking quality by improving the applications' effectiveness. Moreover, a friendly interface design, a secure and convenient mobile banking application should be well-prepared to maintain and build strong relations with their customer and potential customer by improving their satisfaction.

This study contributes to academic literature in developing Islamic mobile banking services relating to four aspects suggested in this study. However, this study is limited to the sample of five top Islamic banks' customers in Indonesia with 100 respondents. Thus, the result of this study cannot be generalized to other countries. This study suggests that further research obtains a broader respondent to provide a comprehensive result representing a general condition of customer satisfaction toward Islamic mobile banking. Moreover, further research can add and modify the variables that may affect customer satisfaction to give better recommendations to strengthen the Islamic mobile banking technology, such as perceived financial cost and perceived risk factor, to improve customer satisfaction determinants.

\section{Author Contributions}

Conceptualization: Bayu Arie Fianto, Charissa Kezia Rahmawati \& Indri Supriani

Data curation: Charissa Kezia Rahmawati \& Indri Supriani

Formal analysis: Bayu Arie Fianto, Charissa Kezia Rahmawati \& Indri Supriani 
Investigation: Charissa Kezia Rahmawati \& Indri Supriani

Methodology: Charissa Kezia Rahmawati \& Indri Supriani

Project administration: Charissa Kezia Rahmawati \& Indri Supriani

Supervision: Bayu Arie Fianto

Validation: Bayu Arie Fianto \& Indri Supriani

Visualization: Charissa Kezia Rahmawati

Writing - original draft: Charissa Kezia Rahmawati \& Indri Supriani

Writing - review \& editing: Indri Supriani

\section{References}

Abd-El-Fattah, S. M., \& Fakhroo, H. A. (2012). The relationship among paternal psychological control and adolescents' perfectionism and self-Esteem: A partial least squares path analysis. Psychology, 03(05), 428-439. https://doi.org/10.4236/psych.2012.35061

Al-Otaibi, S., Aljohani, N. R., Hoque, M. R., \& Alotaibi, F. S. (2018). The satisfaction of Saudi customers toward mobile banking in Saudi Arabia and the United Kingdom. Journal of Global Information Management, 26(1), 85-103. https://doi.org/10.4018/JGIM.2018010105

Alalwan, A. A., Dwivedi, Y. K., \& Rana, N. P. (2017). Factors influencing adoption of mobile banking by Jordanian bank customers: Extending UTAUT2 with trust. International Journal of Information Management, 37(3), 99-110. https://doi.org/10.1016/j.ijinfomgt.2017.01.002

Albashrawi, M., \& Motiwalla, L. (2019). Privacy and personalization in continued usage intention of mobile banking: An integrative perspective. Information Systems Frontiers, 21(5), 10311043. https://doi.org/10.1007/s10796-017-9814-7

Alkhowaiter, W. A. (2020). Digital payment and banking adoption research in Gulf countries: A systematic literature review. International Journal of Information Management, 53, 1-7. 102102. https:// doi.org/10.1016/j.ijinfomgt.2020.102102

Arcand, M., PromTep, S., Brun, I., \& Rajaobelina, L. (2017a). Mobile banking service quality and customer relationships. International Journal of Bank Marketing, 35(7), 1068-1089. https://doi.org/10.1108/IJBM-10-2015-0150

Arcand, M., PromTep, S., Brun, I., \& Rajaobelina, L. (2017b). Mobile banking service quality and customer relationships. International Journal of Bank Marketing, 35(7), 1068-1089. https://doi.org/10.1108/IJBM-10-2015-0150

Arora, S., \& Sandhu, S. (2018). Usage based upon reasons $\square$ : The case of electronic banking services in India. International Journal of Bank Marketing, 36(4), 680-700. https://doi.org/10.1108/IJBM-03-2017-0060

Asad, M. M., Mohajerani, N. S., \& Nourseresh, M. (2016). Prioritizing factors affecting customer satisfaction in the internet banking system based on cause and effect relationships. Procedia Economics and Finance, 36(16), 210-219. https://doi.org/10.1016/s22125671(16)30032-6

Asiamah, M., Ofori, D., \& Afful, J. (2019). Analysis of the determinants of foreign direct investment in Ghana. Journal of Asian Business and Economic Studies, 26(1), 56-75. https://doi.org/10.1108/jabes-08-2018-0057

Asmy, M., Mohd, B., Thaker, T., Amin, F. Bin, Bin, H., Thas, M., Bin, A., \& Pitchay, A. (2018). What keeps Islamic mobile banking customers loyal $\square$ ? Journal of Islamic Marketing, 10(2), 525-541. https://doi.org/10.1108/JIMA-08-2017-0090

Asmy, M., Mohd, B., Thaker, T., Bin, A., Pitchay, A., Bin, H., \& Thas, M. (2019). Factors in fl uencing consumers' adoption of Islamic mobile banking services in Malaysia. Journal of Islamic Marketing, 10(4), 1037-1056. https:/ /doi.org/10.1108/JIMA-04-2018-0065 
Aulia, M., Yustiardhi, A. F., \& Permatasari, R. O. (2020). An overview of Indonesian regulatory framework on Islamic financial technology (fintech). Jurnal Ekonomi \& Keuangan Islam, 6(1), 64-75. https://doi.org/10.20885/jeki.vol6.iss1.art7

Baabdullah, A. M., Alalwan, A. A., Rana, N. P., Kizgin, H., \& Patil, P. (2019). Consumer use of mobile banking (M-Banking) in Saudi Arabia: Towards an integrated model. International Journal of Information Management, 44(September 2018), 38-52. https://doi.org/10.1016/j.ijinfomgt.2018.09.002

Bahl, S., \& Wali, O. P. (2014). Perceived significance of information security governance to predict the information security service quality in software service industry: An empirical analysis. Information Management and Computer Security, 22(1), 2-23. https://doi.org/10.1108/IMCS-01-2013-0002

Bank Indonesia. (2019). Indonesia Payment Systems Blueprint 2025 Bank Indonesia $\square$ : Navigating the National Payment Systems in the Digital Era. Bank Indonesia. https://www.bi.go.id/.../Indonesia-Payment-Systems-Blueprint-2025- Presentation.pdf

Chauhan, V., Yadav, R., \& Choudhary, V. (2019). Analyzing the impact of consumer innovativeness and perceived risk in internet banking adoption: A study of Indian consumers. International Journal of Bank Marketing, 37(1), 323-339. https://doi.org/10.1108/IJBM-02-2018-0028

Chin, W. W. (1998). The partial least squares approach for structural equation modeling. Mahwah, NJ: Lawrence Erlbaum Associates

Darmansyah, D., Fianto, B. A., Hendratmi, A., \& Aziz, P. F. (2020). Factors determining behavioral intentions to use Islamic financial technology: Three competering models. Journal of Islamic Marketing,Vol. abead-of-p (ahead-of-print). https://doi.org/10.1108/JIMA12-2019-0252

Esther, D., Kwame, O. K., \& Kofi, A. B. (2020). Security behaviour of mobile financial service users. In Information \& Computer Security, Vol. ahead-of-p (Issue ahead-of-print). https://doi.org/10.1108/ICS-02-2020-0021

Fall, F. S., Orozco, L., \& Akim, A. M. (2020). Adoption and use of mobile banking by lowincome individuals in Senegal. Review of Development Economics, 24(2), 569-588. https://doi.org/10.1111/rode.12658

Fianto, B. A., Gan, C., Widiastuti, T., \& Sukmana, R. (2020). Customer loyalty to Islamic banks $\square$ : Evidence from Indonesia. Cogent Business \& Management, 7(1), 0-27. https://doi.org/10.1080/23311975.2020.1859849

Foroughi, B., Iranmanesh, M., \& Hyun, S. S. (2019). Understanding the determinants of mobile banking continuance usage intention. Journal of Enterprise Information Management, 32(6), 1015-1033. https://doi.org/10.1108/JEIM-10-2018-0237

Garepasha, A., Aali, S., Bafandeh Zendeh, A. R., \& Iranzadeh, S. (2020). Relationship dynamics in customer loyalty to online banking services. Journal of Islamic Marketing, Vol. ahead-of- $p$ (ahead-of-print). https://doi.org/10.1108/JIMA-09-2019-0183

Ginting, F. G. B., Angelica, N., Kaburuan, E. R., \& Legowo, N. (2020). Implementation plan for augmented reality in the mobile banking application. International Journal of Advanced Science and Technology, 29(5), 2207-2214. Retrieved from http://sersc.org/journals/index.php/IJAST/article/view/10986

Giovanis, A., Assimakopoulos, C., \& Sarmaniotis, C. (2019). Adoption of mobile self-service retail banking technologies: The role of technology, social, channel and personal factors. International Journal of Retail and Distribution Management, 47(9), 894-914. https://doi.org/10.1108/IJRDM-05-2018-0089 
Goodhue, D. L., Lewis, W., Thompson, R., \& Thompson, R. (2018). Does PLS have advantages for small sample size or non-normal data? MIS Quarterly, 36(3), 981-1001. https://doi.org/10.1108/978-1-78756-699-620181001

Haider, M. J., Changchun, G., Akram, T., \& Hussain, S. T. (2018). Exploring gender effects in intention to Islamic mobile banking adoption: An empirical study. Arab Economic and Business Journal, 13(1), 25-38. https://doi.org/10.1016/j.aebj.2018.01.002

Hair, J.F., Black, W. C., Babin, B. J., \& Anderson, R. E. (2010). Multivariate Data Analysis: A Global Perspective (7th ed.). Upper Saddle River, NJ: Pearson Prentice Hall.

Hair, Joe F., Hult, G. T. M., Ringle, C., \& Sarstedt, M. (2011). A Primer on Partial Least Squares Structural Equation Modeling (PLS-SEM). Thousand Oaks, CA: SAGE Publications Inc.

Hair, Joe F., Ringle, C. M., \& Sarstedt, M. (2011). PLS-SEM: Indeed a silver bullet. Journal of Marketing Theory and Practice, 19(2), 139-152. https://doi.org/10.2753/MTP10696679190202

Hamidi, H., \& Safareeyeh, M. (2019). A model to analyze the effect of mobile banking adoption on customer interaction and satisfaction: A case study of $\mathrm{m}$-banking in Iran. Telematics and Informatics, 38, 166-181. https://doi.org/10.1016/j.tele.2018.09.008

Hanafizadeh, P., Behboudi, M., Abedini Koshksaray, A., \& Jalilvand Shirkhani Tabar, M. (2014). Mobile-banking adoption by Iranian bank clients. Telematics and Informatics, 31(1), 62-78. https://doi.org/10.1016/j.tele.2012.11.001

Hellier, P., Geursen, G., Carr, R., \& Rickard, J. (2003). Customer repurchase intention: A general structural equation model. European Journal of Marketing, 37, 1762-1800. https://doi.org/10.1108/03090560310495456

Hong, W., \& Thong, J. (2013). Internet privacy concerns: An integrated conceptualization and four empirical studies. MIS Quarterly, 37, 275-298. https://doi.org/10.25300/MISQ/2013/37.1.12

Imam, P., \& Kpodar, K. (2016). Islamic banking: Good for growth?. Economic Modelling, 59, 387401. https://doi.org/10.1016/j.econmod.2016.08.004

Joe, F. H. J., Marko, S., Lucas, H., \& Volker, G. K. (2014). Partial least squares structural equation modeling (PLS-SEM): An emerging tool in business research. European Business Review, 26(2), 106-121. https://doi.org/10.1108/EBR-10-2013-0128

Kaura, V. (2013). Antecedents of customer satisfaction $\square$ : A study of Indian public and private sector banks. International Journal of Bank. Marketing, 31(3), 167-186. https://doi.org/10.1108/02652321311315285

Kholid, M. N. (2019). Determinants of intention to use Islamic mobile banking: Evidence from millennial generation. Jurnal Ekonomi \& Keuangan Islam, 5(2), 53-62. https://doi.org/10.20885/jeki.vol5.iss2.art2

Koo, C., \& Wati, Y. (2010). Toward an understanding of the mediating role of "trust" in mobile banking service: An empirical test of Indonesia case. Journal of Universal Computer Science, 16(13), 1801-1824. https://doi.org/10.3217/jucs-016-13-1801

Lim, C. J., C., B. N., \& Lim, C. C. (2017). Challenges and factors influencing initial trust and behavioral intention to use mobile banking services in the Philippines. Asia Pacific Journal of Innovation and Entrepreneurship, 11(2), 246-278. https://doi.org/10.1108/APJIE-082017-029

Masrek, M. N., Mohamed, I. S., Daud, N. M., \& Omar, N. (2014). Technology trust and mobile banking satisfaction: A case of Malaysian consumers. Procedia - Social and Behavioral Sciences, 129, 53-58. https://doi.org/10.1016/j.sbspro.2014.03.647 
Mazaheri Asad, M., Mohajerani, N., \& Nourseresh, M. (2016). Prioritizing factors affecting customer satisfaction in the internet banking system based on cause and effect relationships. Procedia Economics and Finance, 36, 210-219. https://doi.org/10.1016/S22125671(16)30032-6

Mbama, C. I., \& Ezepue, P. O. (2018). Digital banking, customer experience and bank financial performance UK customers ' perceptions. International Journal of Bank Marketing, 36(2), 230-255. https://doi.org/10.1108/IJBM-11-2016-0181

Mohammadi, H. (2015). A study of mobile banking loyalty in Iran. Computers in Human Behavior, 44, 35-47. https://doi.org/10.1016/j.chb.2014.11.015

Mohd Thas Thaker, H., Khaliq, A., Ah Mand, A., Iqbal Hussain, H., Mohd Thas Thaker, M. A. Bin, \& Allah Pitchay, A. Bin. (2020). Exploring the drivers of social media marketing in Malaysian Islamic banks: An analysis via smart PLS approach. Journal of Islamic Marketing, Vol. ahead-of-p (ahead-of-print). https:// doi.org/10.1108/JIMA-05-2019-0095

Moliner, M. Á., Monferrer-Tirado, D., \& Estrada-Guillén, M. (2018). Consequences of customer engagement and customer self-brand connection. Journal of Services Marketing, 32(4), 387399. https://doi.org/10.1108/JSM-08-2016-0320

Mostafa, R. B. (2020). Mobile banking service quality: A new avenue for customer value cocreation. International Journal of Bank Marketing, 38(5), 1107-1132. https://doi.org/10.1108/IJBM-11-2019-0421

Motiwalla, L. F., Albashrawi, M., \& Kartal, H. B. (2019). Uncovering unobserved heterogeneity bias: Measuring mobile banking system success. International Journal of Information Management, 49(June), 439-451. https://doi.org/10.1016/j.ijinfomgt.2019.07.005

Octabriyantiningtyas, D., Suryani, E., \& Jatmiko, A. R. (2019). Modeling customer satisfaction with the service quality of E-money in increasing profit of Pt. Telekomunikasi Indonesia. Procedia Computer Science, 161, 943-950. https://doi.org/10.1016/j.procs.2019.11.203

Ofori, K. S., Boateng, H., Okoe, A. F., \& Gvozdanovic, I. (2017). Examining customers ' continuance intentions towards internet banking usage intentions. Marketing Intelligence \& Planning, 35(6), 756-773. https://doi.org/10.1108/MIP-11-2016-0214

Pinho, josé, \& Soares, A. (2011). ExamininPinho, josé, \& Soares, A. (2011). Examining the technology acceptance model in the adoption of social networks. Journal of Research in Interactive Marketing, 5, 116-129. https://doi.org/10.1108/17505931111187767g

Pollari, I., \& Ruddenklau, A. (2018). The Pulse of Fintech 2018. Kpmg, February, 1-75. Retrieved from https://assets.kpmg/content/dam/kpmg/xx/pdf/2019/02/the-pulse-of-fintech2018.pdf

Ramadan, R., \& Aita, J. (2018). A model of mobile payment usage among Arab consumers. International Journal of Bank. Marketing, 36(7), 1213-1234. https:// doi.org/10.1108/IJBM05-2017-0080

Raza, S. A., Umer, A., Qureshi, M. A., \& Dahri, A. S. (2020). Internet banking service quality, ecustomer satisfaction and loyalty: The modified e-SERVQUAL model. The TQM Journal, 32(6), 1443-1466. https://doi.org/10.1108/TQM-02-2020-0019

Rigdon, E. E., Ringle, C. M., \& Sarstedt, M. (2010). Structural modeling of heterogeneous data with partial least squares. In Review of Marketing Research, 7, 255-296 https://doi.org/10.1108/S1548-6435(2010)0000007011

Riyanto, A. D. (2020). Hootsuite (We are Social): Indonesian Digital Report 2020. Retrieved from https:/ / andi.link/hootsuite-we-are-social-indonesian-digital-report-2020/

Safarpour, M. (2016). Identification and ranking the barriers to adoption and development of electronic banking in Iran. Procedia Economics and Finance, 36(2008), 374-380. 
https://doi.org/10.1016/s2212-5671(16)30049-1

Sahoo, D. (2017). Role of mobile banking servicescape on customer attitude and engagement An empirical investigation in India. International Journal of Bank Marketing, 35(7), 1115-1132. https://doi.org/10.1108/IJBM-09-2015-0144

Sampaio, C. H., Ladeira, W. J., \& Santini, F. D. O. (2015). Apps for mobile banking and customer satisfaction: a cross-cultural study. International Journal of Bank Marketing, 35(7), 1133-1153. https://doi.org/10.1108/IJBM-09-2015-0146

Saptasari, K., \& Aji, H. M. (2020). Factors affecting muslim non-customers to use Islamic bank: Religiosity, knowledge, and perceived quality. Jurnal Ekonomi \& Kenangan Islam, 6(2), 165 180. https://doi.org/10.20885/jeki.vol6.iss2.art7

Schermelleh-Engel, K., Moosbrugger, H., \& Müller, H. (2003). Evaluating the fit of structural equation models: Tests of significance and descriptive goodness-of-fit measures. Method of Psychological Research Online, 8(2), 23-74. Retrieved from http:/ /www.mpr-online.de

Sen, S., Antara, N., \& Sen, S. (2020). The determinants of opening account with Islamic banks. Journal of Islamic Marketing, Vol. ahead-of-p (ahead-of-print. https://doi.org/10.1108/JIMA04-2020-0110

Shan-Chun, L., Sunita, B., \& Jay, K. (2003). Technology, service quality, and customer loyalty in hotels: Australian managerial perspectives. Managing Service Quality: An International Journal, 13(5), 423-432. https://doi.org/10.1108/09604520310495886

Shankar, A., \& Rishi, B. (2020). Convenience matter in mobile banking adoption intention? Australasian Marketing Journal, Vol. ahead-of-p (ahead-of-print). https://doi.org/10.1016/j.ausmj.2020.06.008

Shareef, M. A., Baabdullah, A., Dutta, S., Kumar, V., \& Dwivedi, Y. K. (2018). Consumer adoption of mobile banking services: An empirical examination of factors according to adoption stages. Journal of Retailing and Consumer Services, 43(March), 54-67. https://doi.org/10.1016/j.jretconser.2018.03.003

Sharma, S. K., \& Sharma, M. (2019). Examining the role of trust and quality dimensions in the actual usage of mobile banking services: An empirical investigation. International Journal of Information Management, 44(July 2018), 65-75. https://doi.org/10.1016/j.ijinfomgt.2018.09.013

Singh, S., \& Srivastava, R. K. (2020). Understanding the intention to use mobile banking by existing online banking customers: an empirical study. Journal of Financial Services Marketing, Vol. ahead-of-p (ahead-of-print.. https://doi.org/10.1057/s41264-020-00074-w

Siyal, A. W., Donghong, D., Umrani, W. A., Siyal, S., \& Bhand, S. (2019). Predicting mobile banking acceptance and loyalty in Chinese bank customers. SAGE Open, 9(2). https://doi.org/10.1177/2158244019844084

Son, Y., Kwon, H. E., Tayi, G. K., \& Oh, W. (2019). Impact of customers' digital banking adoption on hidden defection: A combined analytical-empirical approach. Journal of Operations Management, 66(4), 418-440. https://doi.org/10.1002/joom.1066

Stewart, H., \& Jürjens, J. (2018a). Data security and consumer trust in FinTech innovation in Germany information \& computer security data security and consumer trust in FinTech innovation in Germany article information $\square$ : Information \& Computer Security, 26(1), 109_ 128. https://doi.org/10.1108/ICS-06-2017-0039

Suhartanto, D., Dean, D., Ismail, T. A. T., \& Sundari, R. (2019). Mobile banking adoption in Islamic banks: Integrating TAM model and religiosity-intention model. Journal of Islamic Marketing, 11(6), 1405-1418. https://doi.org/10.1108/JIMA-05-2019-0096

Tam, C., \& Oliveira, T. (2015). Literature review of mobile banking and individual performance. 
International Journal of Bank Marketing, 35(7), 1044-1067. https://doi.org/10.1108/IJBM09-2015-0143

Tenenhaus, M., Vinzi, V. E., Chatelin, Y. M., \& Lauro, C. (2005). PLS path modeling. Computational Statistics and Data Analysis, 48(1), 159-205. https://doi.org/10.1016/j.csda.2004.03.005

Top Brand Award. (2020a). Survey Methodology. Retrieved from https://www.topbrandaward.com/en/survey-methodology/

Top Brand Award. (2020b). Top Brand Index Fase 1. Retrieved from https://www.topbrandaward.com/en/top-brand-index-int/

Vanessa, R. (2015). A cross-cultural comparison of online behavioural advertising knowledge, online privacy concerns and social networking using the technology acceptance model and social cognitive theory. Journal of Science \& Technology Policy Management, 6(1), 25-36. https://doi.org/10.1108/JSTPM-06-2014-0029

Zameer, H., Tara, A., Kausar, U., \& Mohsin, A. (2015). Impact of service quality, corporate image and customer satisfaction towards customers' perceived value in the banking sector in Pakistan. International Journal of Bank Marketing, 33(4), 442-456. https://doi.org/10.1108/ijbm-01-2014-0015

Zarrouk, H., Ben Jedidia, K., \& Moualhi, M. (2016). Is Islamic bank profitability driven by same forces as conventional banks? International Journal of Islamic and Middle Eastern Finance and Management, 9(1), 46-66. https://doi.org/10.1108/IMEFM-12-2014-0120

Zhou, T. (2011). An empirical examination of initial trust in mobile banking. Internet Research, 21(5), 527-540. https://doi.org/10.1108/10662241111176353

Zhou, T., Lu, Y., \& Wang, B. (2010). Integrating TTF and UTAUT to explain mobile banking user adoption. Computers in Human Behavior, 26(4), 760-767.

https://doi.org/10.1016/j.chb.2010.01.013 